\title{
Corporate Fraud: Does Board Composition Matter?
}

\author{
Caroline Claro Hayek \\ Texas A\&M University-Commerce \\ Guclu Atinc \\ Texas A\&M University-Commerce
}

This study examines the impact of board characteristics (gray directors, multiple directorships and block holder representation on the board) on the occurrence of fraud. Our sample consists of fraud firms where the CEO was involved in fraud, during the period 1997-2007. Our results show that gray directors do not provide appropriate oversight of management and that limiting the number of multiple directorships they hold is associated with a greater likelihood of fraud occurrence. Lastly, we provide evidence of the importance of having block holder representation on the board in an effort to maintain an additional layer of monitoring and deter CEOs from engaging in fraudulent behavior.

\section{INTRODUCTION}

World financial markets were shocked by the Enron scandal when the energy giant went into bankruptcy at the end of 2001, just one year after announcing $\$ 111$ billion revenues in 2000 and being named as "America's Most Innovative Company" by Fortune Magazine for six consecutive years. Several other scandals, such as WorldCom, followed which raised serious questions about the legitimacy of the governance of businesses enterprises globally. Research on the causes of these scandals reveals that weak governance structures and a lack of independence on the board contributed to the CEO's ability to commit fraud within the organization (Beasley, Carcello, Hermanson, \& Ye, 2011; Dechow, Sloan, \& Sweeney, 1996). Since these scandals, there have been several calls to focus on the demographic aspects of the board of directors and of management, in order to understand why highly compensated executives choose to be involved in fraud (Ashford \& Anand, 2003; Nielsen, 2009; Carcello, Hermanson, \& Ye, 2011; Troy, Smith, \& Domino, 2011). The result has been a wealth of multidisciplinary research on firm-level factors, which affirm the linkage between board independence and its effectiveness in reducing the likelihood of fraud.

Surprisingly, only six studies have examined the association between board characteristics and the occurrence of fraud. A seminal study on fraud by Beasley (1996) reveals that the presence of independent or outside directors significantly reduces the likelihood of fraud. A subsequent study by Beasley et al. (2000) suggests that fraud occurs in small companies which are not traded publicly, and these fraud firms have either no audit committee or boards with fewer outside directors. Thus, the inclusion of independent directors on the board is imperative for effective monitoring of management. A third study (Seamer and Psaros, 2000) examined the relationship between the proportion of internal directors, gray directors and independent directors on the board in fraud and no-fraud firms and found support for Beasley (1996). The 
authors reveal that fraud firms have a higher proportion of internal directors and a low proportion of independent directors on the board. Sharma (2004) and Uzun, Szewcyk, and Varma (2004) document that as the percentage of independent directors and independent institutional ownership increases, the likelihood of fraud decreases. Lastly, Farber (2005) finds that fraud firms have fewer independent board members and fewer audit committee meetings relative to fraud firms. In summary, empirical research to date indicates that independence of the board plays a vital role in the occurrence of fraud; with outside independent directors being more effective monitors of management because of their enhanced objectivity.

Despite the above research on independent directors, the potential effect of gray directors on the likelihood of fraud occurring has been scantly examined (Beasley, 2000; Uzun et al., 2004) and warrants further attention. It is important to examine these types of directors because their ability to monitor, from a shareholder's perspective, may be limited due to the non-independent relationships they have with the firm. We therefore aim to fill this void by investigating the specific role of gray directors on firms committing financial fraud and providing further empirical support that the presence of gray directors is associated with fraud. We also contribute to the research stream on multiple directorships by examining whether directors holding multiple directorships influence the occurrence of fraud. Results from prior studies suggest that directors who hold multiple board appointments may be too busy to monitor effectively, thereby impairing effective oversight of management and the financial reporting process (Ferris, Jagannathan, \& Pritchard, 2003; Fich \& Shivdasani, 2006). Our findings extend these studies by examining whether the presence of outside and gray directors holding multiple directorships is related to fraudulent activities. We find that gray directors who hold no multiple directorships are more likely to be associated with the presence of fraudulent activities.

We also fill a gap in the governance literature by examining the distinction between blockholders represented on the board and not represented on the board. This is the first study to provide empirical evidence on the impact of blockholders represented on the board and the presence of fraud. Results show that having blockholder representation on the board is critical for effective monitoring of management. Finally, we contribute to the ongoing debate on director tenure and effective oversight. We provide

evidence that greater tenure on the board is associated with more effective monitoring of management and a lower likelihood of fraud.

\section{THEORETICAL BACKGROUND AND HYPOTHESIS DEVELOPMENT}

\section{Composition of the Board}

One of the key issues related to corporate governance is the composition of the board of directors (Daily \& Dalton, 1992). Walsh and Seward (1990) point out the important role outside directors' play in monitoring and controlling management. Fama and Jensen (1983) suggest that the mix of independent and inside directors affects the board's ability to monitor effectively. Specifically, they indicate that directors derive their power from shareholders in order to control management. When directors have no mutually beneficial relationship with management they will make decisions in the best interest of shareholders and guard against fraudulent behavior. In that regard, independent outside directors should be more effective monitors as they ostensibly have no mutually beneficial relationship with the management they oversee. Thus, their independence affords objectivity, and they are not distracted by personal relationships or financial benefits, which should result in more effective oversight (Kroll, Walters, \& Wright, 2008) and lessen the possibility for fraudulent activities.

Inside directors on the other hand are defined as individuals who are serving on the board of directors and are employed by the company or its subsidiaries (Johnson, Ellstrand, Dalton, \& Dalton, 2004). Most such directors hold an executive office in the company and agency theorists contend insider directors' actions align more with their own best interests rather than those of the shareholders (Kroll, Walters, \& Le, 2007). In addition to the distinction made between inside and outside directors, many scholars distinguish "gray" directors from the truly independent directors. Unlike the truly independent directors, gray directors are directors who are not employed by the company (outside directors) but have indirect 
ties to the company by being relatives of management, consultants to the firm, interlocking directors or retired executives of the firm (Ryan \& Wiggins, 2004; Vicknair, Hickman, \& Carnes, 1993).

Prior studies on gray directors have found mixed evidence on their role in providing effective oversight. Beasley (1996) examines the differences between gray directors and independent directors on the likelihood of fraud and finds no difference, suggesting that the type of director does not play a role in the occurrence of fraud. Two other studies examine the relation between the presence of gray directors on audit committees and external auditor issues. Carcello and Neal (2003) find that the percentage of gray directors is negatively associated with a company receiving a going-concern modified audit opinion while Abbot and Parker (2000) do not find any differences between companies with and without gray directors when choosing an industry specialist as the auditor. Given the limited empirical evidence, and that gray directors can be more easily influenced by management, as documented in the literature, we believe the presence of gray directors on the board may be more conducive to fraudulent activities. We therefore hypothesize as follows:

Hypothesis 1: The percentage of gray directors on the board is positively related to the presence of fraud.

\section{Multiple Directorships}

Previous studies have documented both benefits and shortcomings of directors holding multiple directorships. There are two contrasting viewpoints on whether directors holding multiple directorships can provide effective oversight. One perspective argues that multiple board appointment signals director quality. Directors with a great diversity of experience that serve on the board of successfully financial companies are seen as experts in their area (Fama \& Jensen, 1983; Vafeas, 1999). Multiple directorships are also seen as valuable as they permit other companies to take advantage of directors' contracting relationships and networking contacts (Booth and Deli, 1996). Ferris et al. (2003) examine the relationship between multiple board appointments by directors and the likelihood of securities fraud litigation and find no evidence of inadequate monitoring. Perry and Peyer (2005) investigate multiple directorships' impact on firm outcomes and conclude that additional directorships relate to increased firm value if certain control mechanisms are in place to mitigate potential agency problems.

In contrast, a second perspective, named the "busyness hypothesis" contends that directors serving on multiple boards overcommit their time and are too busy to monitor effectively (Ferris et al., 2003; Fich \& Shivdasani, 2006). Empirical evidence indicates that this busyness by directors is related to excessive CEO compensation and also affects firm performance (Ferris et al., 2003) thereby suggesting directors cannot oversee management effectively (Core, Robert, \& Larcker, 1999). Shivdasani and Yermack (1999) also provide evidence that directors' independence is impaired when directors hold multiple appointments, if the CEO is involved in the board selection process. The main argument is that board members cater to CEOs' wishes and thereby do not represent shareholder interests. In line with the busyness hypothesis, the Council of Institutional Investors (1998) suggests that directors with full-time jobs should not serve on more than two boards while the National Association of Corporate Directors (NACD, 2001) recommends directors not serving on more than three or four boards. More recently, $74 \%$ of the S\&P 500 companies have imposed restrictions on the number of corporate directorships held by their directors, in an effort to reduce "busyness" and improve oversight (Falato, Kadyrzhanova, \& Lei, 2014).

Given the mixed empirical evidence on the effect of multiple directorships on directors' monitoring capability we examine whether the gray directors and independent directors holding multiple directorships is associated with fraud. We contend the presence of independent outside directors who do not hold multiple directorships will be associated with more effective monitoring and a lower likelihood of fraud occurring within organizations. Not only will independent directors be more objective due to their independence, but they are in a better position to monitor as they are less "busy" since they are not immersed in other responsibilities on other boards.

In contrast to independent directors, we contend that gray directors not holding multiple directorships may be less objetive and more likely to be associated with fraud. There are two reasons for this argument. 
First, the independence of gray directors is already viewed as questionable by many agency theorists given that they are more likely to give automatic approval to the decisions of management as a result of their indirect ties to the firm. Consequently, holding multiple directorships may not signal director quality, but rather may contribute to the director being too busy to provide effective oversight along with being easily swayed by his indirect ties to the firm. A second motivation for gray directors being less objective relates to gray directors' inability to maintain other directorships. If gray directors only hold one directorship, they may be more motivated to maintain their seat on the board and less concerned with providing appropriate monitoring. We argue gray directors will not want to challenge management decisions in order to not jeopardize the current benefits they derive from their directorship. For this reason, we consider the presence of gray directors with no multiple directorships to positively impact the likelihood of fraud. Based on the two competing arguments we hypothesize as follows:

Hypothesis 2 $\mathbf{a}_{\mathrm{a}}$ : The presence of gray directors who do not hold multiple directorships is positively related to fraud.

Hypothesis $\mathbf{2}_{\mathrm{b}}$ : The presence of outside directors who do not hold multiple directorships is negatively related to fraud.

\section{Blockholder Ownership}

Blockholder ownership refers to any shareholder who owns at least 5 percent of the voting stock of a company (Sanders \& Boivie, 2004). Blockholder ownership within a firm is important as it serves as an additional control mechanism to improve corporate governance. Blockholders typically have the ability to facilitate takeovers (Shivdasani \& Yermack, 1999) and remove managers who do not maximize shareholder wealth (Kaplan \& Bernadette, 1994; Shivdasani, 1993). Shleifer and Vishny (1986) and Fama and Jensen (1983) suggest that large blockholders have incentives to monitor management, thereby reducing the likelihood of financial statement fraud. Large blockholders can also affect the composition of the board by influencing the selection of the members to the board. Over the years, research investigating the impact of blockholders on board outcomes has found moderate to strong support for improved performance (Dalton, Daily, Certo, \& Roengpitya, 2003; Kroll, Wright, Toombs, \& Leavell, 1997).

It is important to distinguish between blockholders represented on the board and blockholders not represented on the board (Kroll et al., 2008). A blockholder that is represented on the board can have a significant influence on a number of important decisions within the firm. In general, blockholders represented on the board engage in active monitoring as they have continuous access to information and frequent interaction with management through their appointed directors. Moreover, since these blockholders are involved in the decision making process, through its appointed directors, they can influence management decisions at an early stage, identify inadequate managerial decisions and pressure management to act appropriately (Dalton et al., 2003). Having blockholders represented on the board minimizes agency conflict as it aligns the interests of management with those of blockholders, thereby reducing managerial incentives to be opportunistic. Given that blockholders represented on the board can be quite effective monitors, the opposite can be argued for blockholders that are not represented on the board. These types of blockholders typically hold an insignificant amount of common stock, are not represented on the board and have limited knowledge of the decisions made by management. This lack of information consequently reduces the likelihood that these types of blockholders can monitor effectively. Based on the above viewpoints we argue that blockholders that are represented on the board will be more effective monitors and will therefore facilitate an environment where fraudulent activities are mitigated (Jensen \& Meckling, 1976). We hypothesize as follows:

Hypothesis $\mathbf{3}_{\mathrm{a}}$ : The percentage of blockholders represented on the board of directors is negatively related to the presence of fraud. 
Hypothesis $\mathbf{3}_{\mathrm{b}}$ : The percentage of blockholders not represented on the board is positively related to the presence of fraud.

\section{CEO Compensation}

Although the composition of the board plays a vital role in monitoring management, prior empirical research demonstrates that the CEO is typically, either directly involved in the fraud or influences others in committing fraud (Zahra, Priem, \& Rasheed, 2005, 2007), especially when the company's financial performance can affect the CEO's compensation (Zhang, Bartol, Smith, Pfarrer, \& Khanin, 2008). The level of CEO compensation has also been linked to weak corporate governance structures (Sapp, 2008; Tosi \& Gomez-Mejia, 1989; Westphal \& Zajac, 1994; Wright, Kroll \& Elenkov, 2002). For example, CEO compensation has been found to be positively associated with larger boards, the percentage of gray non-executive directors, and CEO duality (Core et al., 1999); all characteristic of weak boards. These results suggest that, assuming the financial motivation is present, the CEO has a greater opportunity to be involved in fraud when boards provide less monitoring.

Several scholars have examined CEO compensation, as well as the compensation of the entire managerial team in order to understand the implications of the CEO pay gap (Carpenter \& Sanders, 2004; Gnyawali, Offstein, \& Lau, 2008). CEO pay gap has been suggested to be an indication of CEO power (Cianci, Guy \& Werner, 2011), where greater CEO power is associated with weaker governance structures. It is defined as the difference between the CEO's pay and the average compensation of the other top management team members (Henderson \& Frederickson, 2001). Research shows that "non-CEO executives earn approximately $40 \%$ of the CEO's compensation" (Conyon \& Muldoon, 2006, p. 28) and that CEO compensation is continuously rising (Useem, 2003). The implication of this occurrence is that as the CEO's compensation rises, the CEO's influence over the board also increases, thereby limiting the board's ability to monitor effectively. Bebchuk, Cremers and Peyer (2007) examined CEO pay gap by comparing CEO compensation to the aggregate compensation of the top five executives (labeled CEO pay slice) and found that CEO pay slice is negatively related to firm performance and shareholder rights and impacted by governance issues.

We believe that as the compensation gap between the CEO and the other executives widens, the CEO will be in a more favorable position to dominate the other executives and exploit any situation that may arise, in his favor. Given that CEO pay gap is an important measure of CEO power that warrants further research, we examine the impact of the CEO pay gap on fraudulent activities. We specifically examine the stock based CEO compensation gap because most CEOs receive a large portion of their compensation in the form of equity (stocks and options) and prior research has shown that high levels of CEO stock compensation are associated with higher level of financial statement fraud (O'Connor, Priem, Coombs, \& Gilley, 2006; Zhang et al., 2008). Based on prior literature, we contend that the stock options pay gap will be positively associated with fraud and therefore hypothesize as follows:

Hypothesis 4: CEO stock-based compensation gap is positively associated with the presence of fraud.

\section{CEO Retirement}

CEO demographics such as age are likely to influence the outcomes of firms (Hambrick, Nadler, \& Tushman, 1998). Hambrick and Mason (1984) argue that age impacts executives' decision-making with younger executives undertaking riskier strategies and exhibiting more aggressive behavior than older executives. They further contend that older executives are more conservative, are better able to judge risks and negative consequences and are less likely to challenge the rules within an organization. Other scholars have found support for these arguments, suggesting younger executives are strategically more aggressive (Brouthers, Brouthers, \& Werner, 2000) and are more susceptible to societal and organizational pressures (Price \& Norris, 2009). Troy et al (2011) examine whether younger CEOs are more likely to engage or faciliate fraud and find that the CEOs of fraud firms are 2 to 3 years younger than the CEOs of non-fraud firms. 
Given that CEO age is a factor in the presence of fraud, we examine whether the time it takes for a CEO to retire (measured in years) has an impact on the occurrence of fraud. We theorize that older CEOs will be in the later stages of their career (ages 50 to 70) as it takes a long time for a seasoned and knowledgeable executive to climb to the top of the professional ladder. We contend that CEOs who are closer to retirement age will not act conservatively, as stipulated in prior literature, but rather will want to maintain their current high living standards or accumulate additional wealth before they retire and thus will be highly motivated to act unethically in order to achieve these financial benefits. We therefore explore whether the time it takes for a CEO to retire is associated with fraud and hypothesize as follows:

Hypothesis 5: CEO time left to retire is negatively related to the presence of fraud.

\section{Director Tenure}

A second demographic-based variable we consider is director tenure. Prior literature suggests that greater years of board service is associated with a lower likelihood of fraud (Beasley, 1996; Beasley et al., 2000; Abbott, Park, \& Parker, 2000; Sharma, 2004). Scholars contend that as years of service increase, the outside director's ability to monitor effectively increases due to the substantial operating knowledge the director has gained over the years. More effective monitoring by the directors thus reduces the likelihood of fraud occurring. Consistent with prior research we examine the relation between director tenure and the occurrence of fraud. We theorize that the longer the director sits on the board of directors, the greater the ability to protect shareholder interests and monitor management (Jensen \& Meckling, 1976). We therefore hypothesize as follows:

Hypothesis 6: Director tenure is negatively related to the presence of fraud.

\section{METHODOLOGY}

\section{Sample Selection}

We use the Lexis-Nexis database to identify firms where the CEO was involved in fraudulent activities between the years 1997 to 2007 (10 year period). We specifically selected companies where the CEO was involved in fraud in order to study these firms' board characteristics and identify traits that impact the likelihood of fraud occurrence. We use the key words fraud, corruption, CEO and fraud, CEO and corruption, executives and fraud, executives and corruption, embezzlement, fraud charge for executives, and fraud charge for CEO in order to identify these firms. If the database did not provide the full story but only briefly discussed a corrupt activity, we referred to the Internet to learn about the details of the story. Initially 94 companies were identified. We then eliminated the financial services companies due to complicated regulations in effect for that industry (Schnatterly, 2003), and firms where fraudulent activities were not specifically performed by the CEO. Financial data was collected from Compustat and proxy statements for the year the fraud occurred, or if the fraud occurred over several years, the first year the fraud occurred. After eliminating several companies due to missing data, we had a final sample of 68 fraud companies.

The Schnatterly (2003) procedure was then used and modified as follows to identify the matched pairs:

Step 1: Each company's SIC code is identified using Disclosers and Hoover's Databases

Step 2: The list of companies with the same SIC code from the fraud year (if fraud took place over several years, the first year it took place is considered) is identified using Disclosures Database

Step 3: Total Assets and Number of Employees values of every company are gathered using the Disclosures Database

Step 4: If any of these items are missing for any company, that company is eliminated from the list

Step 5: The companies are first ranked based on Total Assets and assigned a rank number starting from 1 assigned to the company with the lowest amount of assets 
Step 6: The companies are ranked based on number of employees and once again assigned a second rank number as mentioned in Step 5

Step 7: The previously assigned rank numbers are summed and companies are ranked in ascending order based on that index number

Step 8: In the final step, the company that is closest in the ranking to the focal company is chosen to be the matched pair

Using the above procedure, 68 additional companies were identified as control non-fraud firms, thereby resulting in 136 companies being included in our study. Due to missing financial data, four more companies were eliminated which brought the final sample size to 132 companies (66 matched pairs).

\section{Description of Variables}

Independent Variables of Interest

PGray: As Ryan and Wiggins (2004) defines, gray directors are directors that have an indirect relationship with the company or have had a connection in the past, such as being a retired executive. The percentage of gray directors is calculated by taking the number of gray directors divided by total number of directors.

POutside: Any director who has no affiliation with the company whatsoever other than serving on the board is marked as independent outside director (Wright et al., 2002). Percentage of outside directors (Poutside) is calculated as the number of outside directors divided by total number of directors.

PreInsW: If the director of the focal firm is a director or executive in another firm, that director is considered to be holding an interlocking directorship (Mizruchi, 1996). The previously identified inside, outside and gray directors are also marked as interlocking or non-interlocking directors. The presence of inside (PreInsW) directors holding directorships in other companies is marked as binary variables (1 for Yes, 0 otherwise).

PreOutNW, PreGraNW: The presence of outside directors and gray directors holding no multiple directorships are operationalized as binary variables. We code the varaiables as 1 if a director holds only a directorship at the current firm and has no other directorships and 0 otherwise.

PerBloOB, PerBloNB: Blockholders are shareholders with 5 percent or more of firm's outstanding shares (Kroll et al., 1997). Percentage of blockholders represented on the board (PerBloOB) is calculated by taking the number of blockholders represented on the board divided by the total number of directors. Also, the percentage of blockholders not represented on the board (PerBloNB) is calculated by the number of blockholders not represented on the board divided by total number of blockholders (Kroll et al., 2008). If the company did not have any blockholders, listwise deletion method is used to eliminate those companies from the quantitative analysis.

PreCGap, PreOpGap: CEO Compensation gap is calculated by subtracting the average compensation of the other executives from the CEO's compensation (Henderson \& Frederickson, 2001). A distinction has been made for cash-based compensation and stock-based (option rewards) compensation. Cash-based included all the monetary rewards given to the executives other than the number of stocks offered as stock options. The presence of positive cash-based compensation gap (PreCGap) and positive options gap (PreOpGap) are coded as dummy variables.

RetCEO: The executive's age is subtracted from 65 for each company (Weisbach, 1995) to represent the time left for retirement for each CEO. In case the executive is older than 65 the value is replaced by zero to indicate retirement age. 
DTenure: The average time the directors served on the board is calculated by summing all the directors tenure on the board and dividing by the number of directors (Harrison, Price, \& Bell, 1998).

\section{Control Variables}

Control variables for the various models are discussed below, however firm size is not included as a control variable in the models because our sample procedures used to identify matched pairs already controls for firm size (see Sample Selection Section).

SalesP: In order to calculate sales growth pressure, we first identified the previous 5 years' average sales growth for each company using Disclosures database. A binary variable (SalesP) is used to operationalize the possibility of pressure exerted on management due to low performance. If the previous 5 years sales growth is negative, this variable is coded as 1 and 0 if it is positive.

Duality: CEO duality refers to the same person performing the duties of both the CEO and the Chairman of the Board (Desai, Kroll, \& Wright, 2003). Presence of duality has be shown to be related to fraudulent reporting (O'Connor et al., 2006) therefore we control for duality in our study. A binary variable is used to represent the presence of duality.

RetDir: Since we hypothesize the CEO's time left for retirement to be related to fraudulent activities, the impact of director's time left to retire may also be relevant in mitigating CEO pressure during this tenure with the company. We calculated RetDir by taking the average age of all the directors and subtracting from 65 (the age of retirement).

CEOAge and Director AvgAge: We control for CEO age and the average age of the directors because demographic dissimilarity has an impact on fraudulent behavior within organizations.

Table 1 below lists the variables used in our analysis and their definitions.

\section{TABLE 1 \\ DESCRIPTION OF VARIABLES}

\begin{tabular}{ll}
\hline Main Dependent and Test Variables & \\
Variable Name & Description/Variable Measurement \\
\hline FRAUD & $\begin{array}{l}\text { Binary variable indicating whether fraud is present or not. } \\
\text { Coded } 1 \text { if a company has been involved in fraud and } 0 \\
\text { otherwise. }\end{array}$ \\
PGRAY & $\begin{array}{l}\text { Percentage of gray directors. Number of gray directors } \\
\text { divided by total number of directors. }\end{array}$ \\
POUTSIDE & $\begin{array}{l}\text { Percentage of outside directors. Number of outside } \\
\text { directors divided by total number of directors. }\end{array}$ \\
PREINSW & $\begin{array}{l}\text { Presence of inside directors holding directorships. Coded } \\
\text { as } 1 \text { if holding directorships and } 0 \text { otherwise. } \\
\text { Presence of outside directors who hold no multiple } \\
\text { directorships. Coded } 1 \text { if a director holds only one } \\
\text { directorship at the current firm and } 0 \text { otherwise. }\end{array}$ \\
PREOUTNW & $\begin{array}{l}\text { Presence of gray directors who hold no multiple } \\
\text { directorships. Coded } 1 \text { if a director holds only one } \\
\text { directorship at the current firm and } 0 \text { otherwise. }\end{array}$ \\
PREGRANW &
\end{tabular}


PERBLOOB

PERBLONB

PRECGAP

PREOGAP

RETCEO

DTEN
Percentage of block holders represented on the board. Number of block holders represented on the board divided by total number of directors.

Percentage of block holders not represented on the board. Number of block holders not represented on the board divided by total number of directors.

Presence of positive cash-based compensation gap. CEO compensation less the average compensation of the other executives.

Presence of positive option-based compensation gap. CEO compensation less the average compensation of the other executives.

Time left for CEO to retire. CEO's age subtracted from 65 (age of retirement).

Average tenure on the board. Sum of all directors tenure on the board divided by the total number of directors.

\section{Control Variables}

Variable Name

\section{DUALITY}

SALESP

RETDIR

CEO AGE

DIRAVGAGE

\section{Description/Variable Measurement}

CEO serves as the Chairman of the board. Coded 1 if the CEO is the Chairman and 0 otherwise. Sales growth pressure exerted on management. We first calculated the average of the previous 5 years sales growth. If the previous 5 years sales growth is negative it is coded a 1 , and coded 0 if it is positive.

Time left for directors to retire. Average age of the directors on the board subtracted from 65 (age of retirement).

Average Age of the CEO.

Average age of directors.

\section{EMPIRICAL RESULTS}

We initially run an ANOVA in order to compare the fraud companies to the non-fraud companies and assess if both groups are different. The dependent variable in each regression is the binary variable FRAUD, which indicates whether fraud was present or not. The dummy variable took a value of 1 when a company had fraud committed within the organization and a value of 0 otherwise. Regression models were then used to test the various hypotheses, using the following governance variables as independent variables: Gray directors, independent outside directors, blockholders, CEO compensation gap, CEO tenure and Director tenure. We use sales growth pressure, CEO duality, CEO age and Director age as control variables in our model. The focus of our study is to examine various board characteristics and its impact on a company being engaged in fraudulent activities.

The various regression models are as follows: 
Model $1 \quad$ Fraud $=\beta_{0}+\beta_{1}$ PGray $+\beta_{2}$ SalesP $+\beta_{3}$ Duality

Model $2 \quad$ Fraud $=\beta_{0}+\beta_{1}$ PreInsW $+\beta_{2}$ PreGrayNW $+\beta_{3}$ PreOutNW $+\beta_{4}$ SalesP $+\beta_{5}$ Duality

Model 3a $\quad$ Fraud $=\beta_{\mathrm{o}}+\beta_{1}$ PerBloOB $+\beta_{2}$ SalesP $+\beta_{3}$ Duality

Model $3 b \quad$ Fraud $=\beta_{\mathrm{o}}+\beta_{1}$ PerBloNB $+\beta_{2}$ SalesP $+\beta_{3}$ Duality

Model $4 \quad$ Fraud $=\beta_{\mathrm{o}}+\beta_{1}$ PreCGap $+\beta_{2}$ SPreOpGap $+\beta_{3}$ SalesP $+\beta_{4}$ Duality

Model $5 \quad$ Fraud $=\beta_{\mathrm{o}}+\beta_{1}$ DTen $+\beta_{2}$ RetCEO $+\beta_{3}$ RetDir $+\beta_{4}$ DirAveAge $+\beta_{5}$ CEOAge

Table 2 presents one-way ANOVA results. Using Fraud variable as the factor, the differences between the groups based on the individual independent variables are assessed using one-way ANOVA. As shown in Table 2, the difference between fraud firms and non-fraud companies is significant for Percentage of Gray Directors on the Board, Presence of outside directors with no other directorships, Percentage of Blockholders represented on the board, Percentage of Blockholders not represented on the board and Average Director Tenure. These initial traits indicate the potential impact some of our independent variables have on the dependent variable (Fraud).

TABLE 2 ANOVE RESULTS

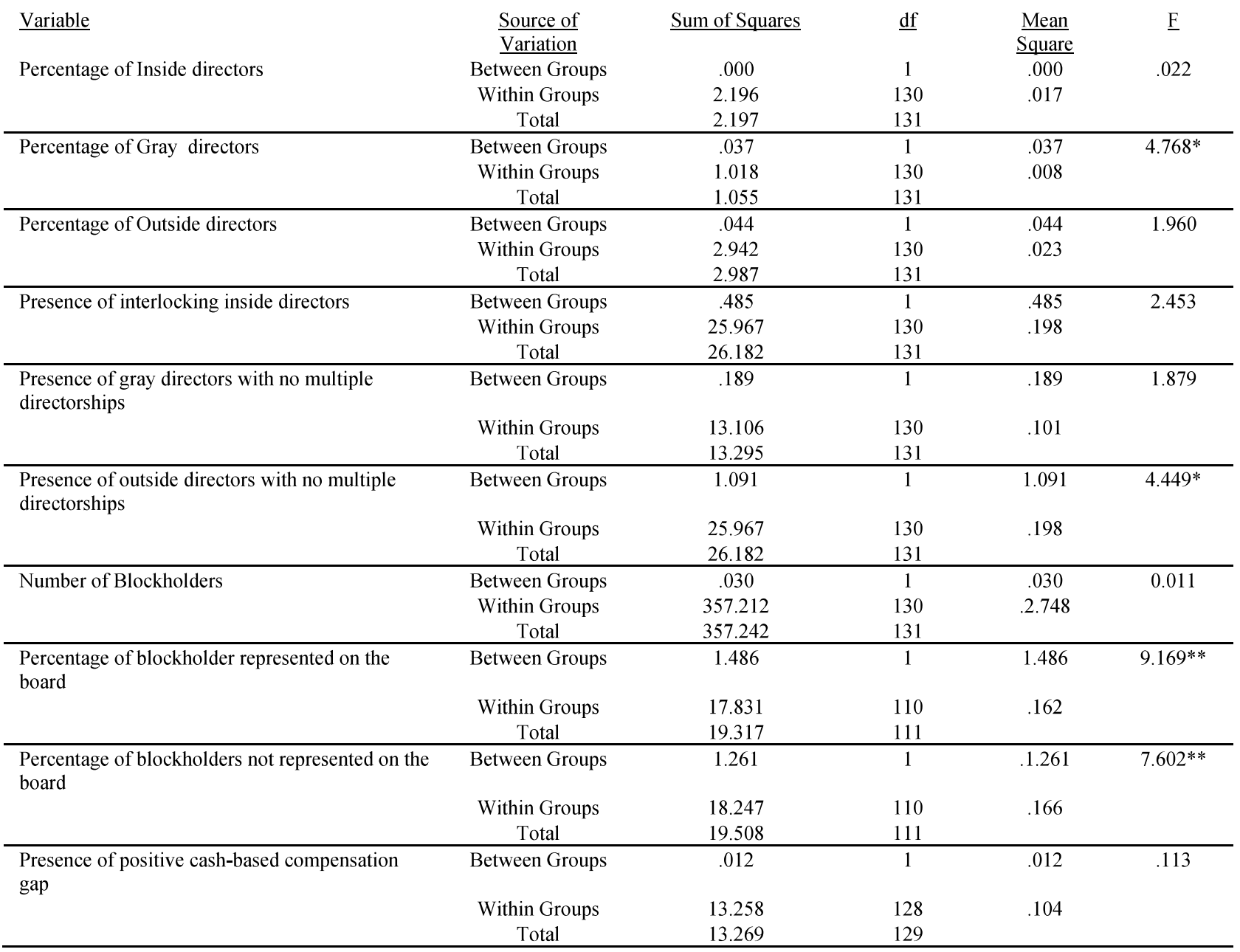




\begin{tabular}{|c|c|c|c|c|c|}
\hline Presence of positive options based compensation & $\begin{array}{c}\text { Between Groups } \\
\text { Within Groups } \\
\text { Total } \\
\end{array}$ & $\begin{array}{c}.018 \\
23.059 \\
23.077 \\
\end{array}$ & $\begin{array}{c}1 \\
128 \\
129 \\
\end{array}$ & $\begin{array}{r}.018 \\
.180\end{array}$ & .101 \\
\hline Time top retirement (CEO) & $\begin{array}{c}\text { Between Groups } \\
\text { Within Groups } \\
\text { Total } \\
\end{array}$ & $\begin{array}{c}86.735 \\
8236.924 \\
8323.659 \\
\end{array}$ & $\begin{array}{c}1 \\
130 \\
131 \\
\end{array}$ & $\begin{array}{l}86.735 \\
63.361\end{array}$ & 1.369 \\
\hline Director Tenure & $\begin{array}{c}\text { Between Groups } \\
\text { Within Groups } \\
\text { Total } \\
\end{array}$ & $\begin{array}{c}73.383 \\
1474.202 \\
1547.584 \\
\end{array}$ & $\begin{array}{c}1 \\
130 \\
131 \\
\end{array}$ & $\begin{array}{l}73.383 \\
11.340\end{array}$ & $6.471^{*}$ \\
\hline Board Size & $\begin{array}{c}\text { Between Groups } \\
\text { Within Groups } \\
\text { Total }\end{array}$ & $\begin{array}{c}.189 \\
1684.742 \\
1684.932 \\
\end{array}$ & $\begin{array}{c}1 \\
130 \\
131 \\
\end{array}$ & $\begin{array}{c}.189 \\
12.960\end{array}$ & .015 \\
\hline
\end{tabular}

Note. ${ }^{*} \mathrm{p}<.05 ; * * \mathrm{p}<.01$.

Table 3 presents the results of the Logistic Regression Models. As expected in Hypothesis 1, we see that Percentage of gray directors in Model 1 is significant and positively related to the presence of fraud $(\beta=4.735, p<0.05)$. These results suggest that gray directors are not as vigilant and objective as truly independent outside directors, consistent with prior research, and that their monitoring capabilities are diminished by the personal indirect ties they have with management. Hence, this less effective monitoring by gray directors seems to provide an opportunity for the likelihood of fraud to occur within an organization.

In Model 2, we find that the presence of gray directors with no multiple directorships is significantly and positively related to the dependent variable $(\beta=1.331, \mathrm{p}<0.05)$ as hypothesized. These results seem to suggest that gray directors who do not hold other directorships are more likely to be associated with the presence of fraudulent activities. One explanation for these results may be that directors who only hold one directorship have less opportunities to increase their wealth and reputation and are therefore more susceptible to succumbing to management's wishes in order to ensure they receive the monetary rewards they expect.

We also find that the presence of outside directors with no multiple directorships is significant but negatively related to the presence of fraud $(\beta=-9.39, \mathrm{p}<0.05)$ as hypothesized. These results are not surprising as prior research has already established that independent outside directors provide more effective monitoring and are motivated to act in the best interests of shareholders. We therefore suggest that having no other directorships beside the focal one allows independent directors to focus solely on matters related to that company and not be distracted with other outside duties. The result is more effective oversight and a lower likelihood that fraud may occur.

Results for our tests of $\mathrm{H}_{3}, \mathrm{H}_{3}$, are also reported in Table 3. We find support for both of our hypotheses. Percentage of blockholders represented on the board in Model $3_{\mathrm{a}}$ is significant and negatively related $(\beta=-1.428, p<0.01)$ and percentage of blockholders not represented on the board in Model $3_{b}$ is significant and positively $(\beta=1.264, p<0.01)$ related to the presence of fraud. The negative relation found in $\mathrm{H} 3{ }_{\mathrm{a}}$ suggests that being represented on the board is associated with more monitoring. In contrast, blockholders that are not represented on the board are at a disadvantage as they cannot closely monitor the actions of management, thus implying that there is weaker monitoring and thereby increasing the likelihood of fraud occurring. From management's perspective, having a company where several blockholders are not representated on the board provides them with a greater opportunity to act unethically as external monitoring is weak. In summary, the positive relation found between blockholders not represented on the board and the presence of fraud only confirms how important it is to have blockholders represented on the board of directors.

Neither the presence of positive cash-based compensation gap nor the presence of positive stockbased (options) compensation (H4) in Model 4 were found to be significant with the dependent variable. The lack of empirical results for cash-based compensation gap may be due to CEOs receiving a greater proportion of their compensation in the form of equity rather than cash compensation (Knight, 2002). Prior research has already established that compensating directors with a greater proportion of equity compensation seems to align the interests of directors with those of shareholders (NACD, 2001). 
We expected to find that positive stock-based (options) compensation would be associated with the presence of fraud however, this hypothesis is not supported by our data. Given that other scholars have found that CEO stock options are positively associated with fraud (William \& Rao, 2006; Yermack, 1997) we interpret this lack of significance to mean that stock option compensation may not be the driving force in motivating CEOs to encourage fraudulent behavior. Lastly, we believe the lack of support for both hypotheses may also be a result of having operationalized the variables as binary to represent the presence of positive cash-based compensation and stock-based compensation gaps. Given the use of binary variables, the size of our sample may not be large enough to find any variance.

Finally, Model 5 is used to test Hypotheses 5 and 6. We found no support for Hypothesis 5 which proposes CEO's time left to retire is negatively related with the presence of fraud. These results suggest that the occurrence of fraud is not sensitive to how much time the CEO has left to retire. Rather, we contend that other CEO and board demographics may play a joint role in the occurrence of fraud (reference). In contrast, we find support for H6, consistent with director tenure literature, that director tenure is significantly and negatively related to the presence of fraud $(\beta=-0.144, p<0.05)$. The implications of these findings are that greater director tenure provides more effective monitoring of management and lowers the likelihood that fraud can occur.

TABLE 3

\section{LOGISTIC REGRESSION RESULTS}

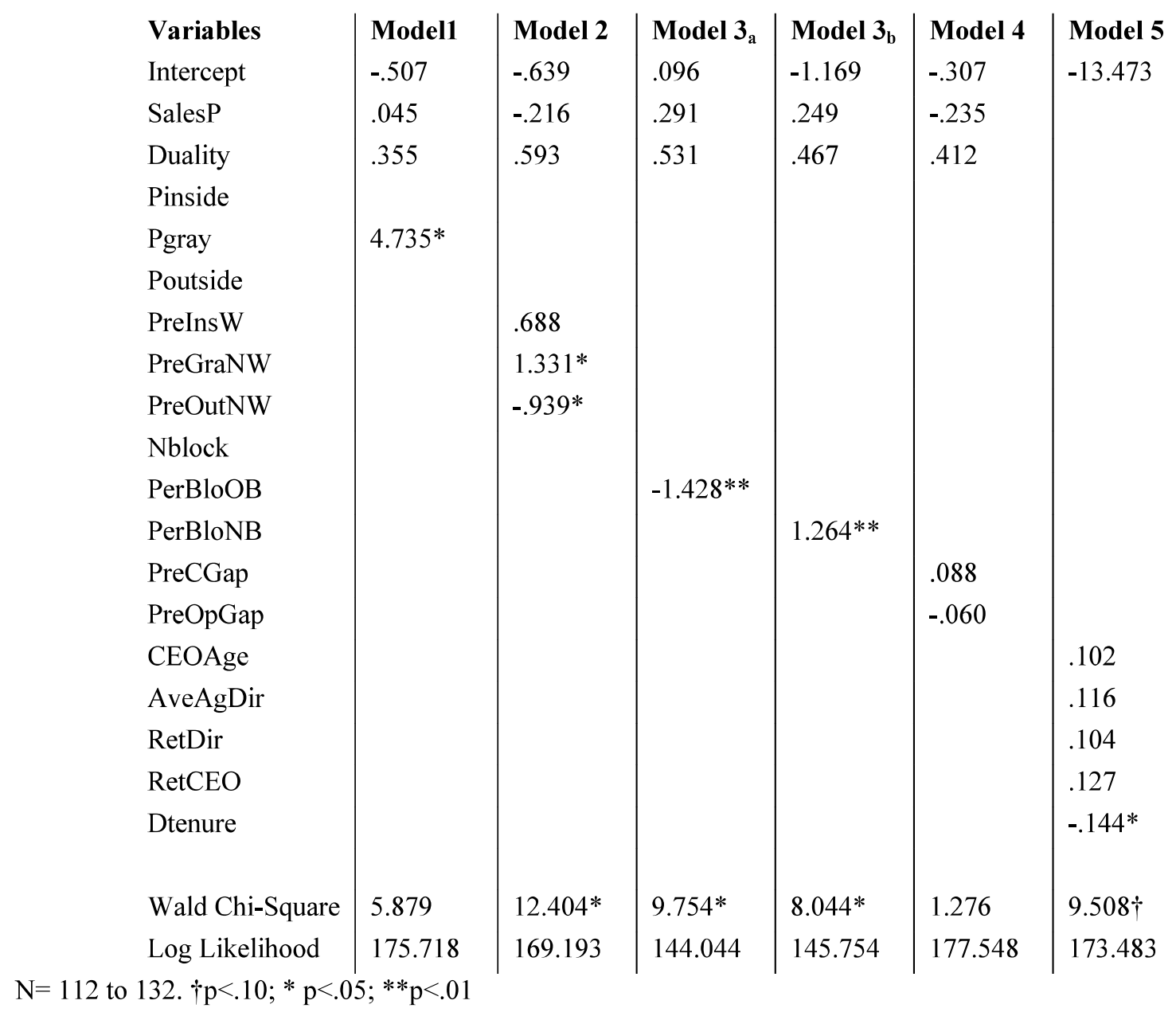




\section{CONCLUSION}

Fraud continues to occur in the twenty-first century despite Congress having passed the SarbanesOxley Act of 2002 in an attempt to strengthen the quality of corporate governance provided by independent directors (SOX, 2002). This study therefore aims to augment the limited empirical evidence on the relation between board characteristics and the occurrence of fraud in an effort to identify additional board factors that mitigate the CEO's ability to commit fraud.

We find that gray directors are not as effective at providing appropriate monitoring due to the indirect relationships they maintain within the firm. Their lack of independence and weak oversight seems to be associated with a greater likelihood of fraudulent behavior within the organization. Of larger significance are the findings related to gray and outside directors that hold no multiple directorships. We find that when gray directors do not hold multiple directorships they are more likely to be associated with fraud due to their close ties to the organization and the board. Since these type of directors do not have the ability to gain additional wealth by holding other appointments they are more likely to monitor less effectively in order to maintain their current directorship. In contrast, we find that outside directors who hold no multiple directors provide more monitoring and are associated with a lower likelihood of fraud occurring. The main implication of these findings is that limiting the quantity of directorships a gray director can hold, may not enhance oversight as suggested by the NACD and the Council of Institutional Investors.

We also filled a void in the literature by examining the distinction between blockholder representation on the board and blockholders with no representation, and its effect on fraudulent behavior. The results suggest that it is critical to have blockholder representation on the board in an effort to have another layer of monitoring of management, as blockholders who are not represented cannot monitor effectively. Lastly, our results on director tenure reinforce the view that greater years of service on the board improve director oversight.

In summary, our results provide fruitful contributions to the corporate governance research by exploring the effects gray directors and blockholders have on the occurrence of fraud. We encourage practitioners and regulators to further examine these board characteristics, as deeper analysis of these governance features may draw further insight into the optimal board structure for deterring CEOs from engaging in fraudulent behavior. 


\section{REFERENCES}

Abbott, L.J., Park, Y. \& Parker, S. (2000). The effects of audit committee activity and independence on corporate fraud. Managerial Finance, 26, 55-67.

Ashford, B.E., \& Anand, V. (2003). The normalization of corruption in organizations. Research in Organizational Behavior, 25, 1-52.

Beasley, M.S. (1996). An empirical analysis of the relation between the board of director composition and financial statement fraud. The Accounting Review, 71, 443-465.

Beasley, M.S., Carcello, J.H., Hermanson, D.R. \& Lapides, P.D. (2000). Fraudulent financial reporting: Consideration of industry traits and corporate governance mechanisms. Accounting Horizons, 14, 441-454.

Bebchuk, L. A., Cremers, M., \& Peyer, U. (2007). CEO centrality (No. w13701). National Bureau of Economic Research

Booth, J. R., \& Deli, D. N. (1996). Factors affecting the number of outside directorships held by CEOs. Journal of Financial Economics, 40, 81-104.

Brouthers, K.D., Brouthers, L.E., Werner, S. (2000). Influences on strategic decision-making in the Dutch financial services industry. Journal of Management, 26, 863-883.Carcello, J. V., \& Neal, T. L. (2003). Audit committee characteristics and auditor dismissals following "new" going-concern reports. The Accounting Review, 78 (1), 95-117.

Carcello, J.F., Hermanson, D.R., \& Ye, Z. (2011). Corporate governance research in accounting and auditing: Insights, practice implications, and future research directions. Auditing: A Journal of Practie \& Theory, 30 (3), 1-31.

Carpenter, M. A., \& Sanders, W.G. (2004). The effects of top management team pay and firm internalization on MNC performance.Journal of Management, 30, 509-528.

Cianci, A.M., Guy, D.F. \& Werner, M.W. (2011). The differential CEO dominance-compensation and corporate governance compensation relations: Pre- and post-Sox. Advances in Accounting, incorporating Advances in International Accounting, 27, 213-222.

Conyon, M. J., \& Muldoon, M. R. (2006). The small world of corporate boards. Journal of Business Finance \& Accounting, 33 (9-10), 1321-1343.

Core, J. E., Robert, W. H., \& Larcker, D. F. (1999). Corporate governance, CEO Compensation, and firm performance. Journal of Financial Economics, 51, 371-406.

Council of Institutional Investors. (1998). Core policies, positions and explanatory notes. Washington, D.C.

Daily, D., \& Dalton, C. (1992). The relationship between governance structure and corporate performance in entrepreneurial firms. Journal of Business Venturing, 7, 375-386.

Dalton, D., Daily, C., Certo, S., \& Roengpitya, R. (2003). Meta-Analyses of financial performance and equity: fusion or confusion? Academy of Management Journal, 46, 13-26.

Dechow, P.M., Sloan, R.G. \& Sweeney, A.P. (1996). Causes and consequences of earnings manipulations: An analysis of firmssubject to enforcement actions by the SEC. Contemporary Accounting Research, Spring, 1-36.

Desai, A., Kroll, M., \& Wright, P. (2003). CEO Duality, board monitoring and acquisition performance: a test of competing theories. Journal of Business Strategies, 20 (2), 137-156.

Falato, A., Kadyrzhanova, D., \& Lei, U. (2014). Distracted directors: Does board busyness hurt shareholder value? Journal of Financial Economics, 113, 404-426.

Fama, E., \& Jensen, M. (1983). Seperation of ownership and control. Journal of Law and Economics, 26, 301-325.

Farber, D.B. (2005). Restoring trust after fraud: Does corporate governance matter? The Accounting Review, 80(2), 539-561.

Ferris, S. P., Jagannathan, M., \& Pritchard, A. C. (2003). Too Busy to Mind the Business? Monitoring by Directors with Multiple Board Appointments. Journal of Finance, 58 (3), 1087-1111.Fich, E.M., $\&$ Shivdasani, A. (2006). Are busy boards effective monitors? Journal of Finance, 61, 689-724. 
Gnyawali, D. R., Offstein, E. H., \& Lau, R. S. (2008). The impact of the CEO pay gap on firm competitive behavior. Group \& Organization Management, 33 (4), 453-484

Hambrick, D. C., \& Mason, P. (1984). Upper Echelons: The Organization as a Reflection of Its Top Managers. Academy of Management Review, 9 (2), 193-206.

Hambrick, D., Nadler, D., \& Tushman, M. (1998). Navigating Change: How CEO's top teams and boards steer transformation. Boston: Harvard Business School.

Harrison, D. A., Price, K. H., \& Bell, M. P. (1998). Beyond Relational Demography: Time and Effects of Surface- and Deep-Level Diversity on Work Group Cohesion. Academy of Management Journal, 41 (1), 96-107.

Henderson, A., \& Frederickson, J. (2001). Top management team coordination needs and CEO Pay Gap: A competitive test of economic and behavirol views. Academy of Management Journal, 44, 96117.

Jensen, M., \& Meckling, W. (1976). Theory of the firm: Managerial Behavior, Agency Costs and Ownership Structure. Journal of Financial Economics, 3, 305-360.

Johnson, J., Ellstrand, A., Dalton, C., \& Dalton, D. (2004). A Fine-Grained Analysis of Director Dependence: Examining Board Composition in Detail. Journal of Business Strategies, 21 (2), 111-123.

Kaplan, S.N., \& Bernadette, A.M.(1994). Appointments of outsiders to Japanese boards: Determinants and implications for managers. Journal of Financial Economics, 36, 225-258.

Knight, J. (2002). Performance and greed. Journal of Business Strategy, 23, 24-27.

Kroll, M., Walters, B., \& Le, S. (2007). The Impact of Board Composition and Top Management Team Ownership Structure on Post-IPO Performance in Young Entrepreneurial Firms. Academy of Management Journal, 50 (5), 1198-1126.

Kroll, M., Walters, B., \& Wright, P. (2008). Board vigilance, director experience, and corporate outcomes. Strategic Management Journal, 29 (4), 363-382.

Kroll, M., Wright, P., Toombs, L., \& Leavell, H. (1997). Form of controll: a critical determinant of acquisition performance and CEO rewards. Strategic Manegement Journal, 18, 85-96.

Mizruchi, M. S. (1996). What do Interlocks Do? An Analysis, Critique and Assessment of Reserach on Interlocking Directorates. Annual Review of Sociology, 22, 271-298.

National Association of Corporate Directors (NACD), (2001). Director Compensation: Purpose, principles and best practices. Washington, D.C.: The National Association of Corporate Directors.

Nielsen, S. (2009). Why do top management teams look the way they do? A multilevel exploration of the antecedents of TMT heterogeneity. Strategic Organization, 7 (4), 277-305.

O'Connor, J. P., Priem, R. L., Coombs, J. E., \& Gilley, M. K. (2006). Do CEO Stock Options Prevent or Promote Fradulent Financial Reporting? Academy of Manegement Journal, 49 (3), 483-500.

Perry, T., \& Peyer, U. (2005). Board Seat Accumulation by Executives: A Shareholder's Perspective. The Journal of Finance, 60 (4), 2083-2123.

Price, M. \& Norris, D. (2009). White-collar crime: Corporate and securities and commodities fraud. The Journal of the American Academy of Psychiatry and the Law, 37, 538-544.

Ryan, H., \& Wiggins, R. (2004). Who is in whose pocket? Director compensation, board independence, and barriers to effective monitoring. Journal of Financial Economics, 73 (3), 497-524.

Sanders, G. W., \& Boivie, S. (2004). Sorting things out: Valuation of New Firms in Uncertain Markets. Strategic Management Journal, 25 (2), 167-186.

Sapp, S. G. (2008). The impact of corporate governance on executive compensation. European Financial Management, 14 (4), 710-746

Sarbanes-Oxley Act of 2002. The Public Company Accounting Reform and Investor Protection Act. Retrieved from http://whitehouse.gov/infocus/corporate responsibility.

Schnatterly, K. (2003). Increasing Firm Value Through Detection and Prevention of White-Collar Crime. Strategic Management Journal, 24 (7), 587-614. 
Seamer, M., \& Psaros, J. (2000). Board composition and the incidence of management perpetrated fraud. Working paper, The University of New South Wales.

Sharma, V.D. (2004). Board of director characteristics, institutional ownership and fraud: Evidence from Australia. Auditing: A Journal of Practice \& Theory, 23 (2), 105-117.

Shivdasani, A. (1993). Board composition, ownership structure and hostile takeovers. Journal of Accounting and Economics, 16, 167-198.

Shivdasani, A., \& Yermack, D. (1999). CEO involvement in the selection of new baord members: an empirical analysis. Journal of Finance, 54, 1829-1853.

Shleifer, A. \& Vishny, R.W. (1986). Large shareholders and corporate control. Journal of Political Economy, 94, 461-488.

Tosi, H., \& Gomez-Mejia, L. (1989). The decoupling of CEO pay and performance: An agency theory perspective. Administrative Science Quarterly, 34, 169-190.

Troy, C., Smith, K.G., \& Domino, M.A. (2011). CEO demographics and accounting fraud: Who is more likely to rationalize illegal acts. Strategic Organization, 94 (4), 259-282.

Useem, M. (2003). Corporate governance is directors making decisions: Reforming the outward foundations for inside decision making. Journal of Management and Governance, 7 (3), 241-253.

Uzun, H., Szewczyk, S.H., \& Varma, R. (2004). Board composition and corporate fraud. Financial Analyst Journal, May/June, 33-43.

Vafeas, N. (1999). Board meeting frequency and firm performance. Journal of Financial Economics, 53 (1), 113-142.

Vicknair, D., Hickman, K., \& Carnes, K.C. (1993). A note on audit committee independence: Evidence from the NYSE on "Grey" Area Directors. Accounting Horizons, 7 (1), 53-57.

Walsh, J., \& Seward, J. (1990). On the efficiency of internal amd external corporate control mechanisms. Academy of Management Review, 15 (3), 421-458.

Weisbach, M. S. (1995). CEO Turnover and the firm's investment decisions. Journal of Financial Economics, 37 (2), 159-188.

Westphal, J., \& Zajac, E. (1994). Substance and symbolism in CEo's long-term incentive plans. Administrative Science Quarterly, 39, 367-390.

Williams, M. A., \& Rao, R. P. (2006). CEO stock options and equity risk incentives. Journal of Business Finance \& Accounting, 33 (1-2), 26-44

Wright, P., Kroll, M., \& Elenkov, D. (2002). Acquisition returns, increase in firm size, and chief executive office compensation: The moderating role of monitoring. Academy of Management Journal, 43 (3), 599.

Yermack, D. (1997). Good timing: CEO stock option awards and company news announcements. The journal of Finance, 52 (2), 449-476

Zahra, S.A., Priem, R.L., \& Rasheed, A.A. (2005). The antecedents and consequences of top management fraud. Journal of Management, 31, 803-28.

Zahra, S.A., Priem, R.L., \& Rasheed, A.A. (2007). Understanding the causes and effects of top management fraud. Organizational Dynamics, 36 (2), 122-139.

Zhang, X., Bartol, K., Smith, K., Pfarrer, M., \& Khanin, D. (2008). CEOs On the Edge: Earnings Manipulation and Stock-BAsed Incentive Misalignment. Academy of Management Journal, 51 (2), 241-258. 